\title{
Production of Bacterial Cellulose from Gluconacetobacter persimmonis GH-2 using Dual and Cheaper Carbon Sources
}

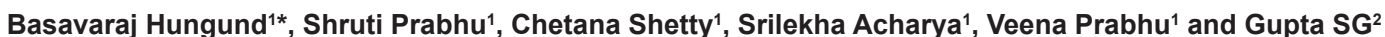

${ }^{1}$ Department of Biotechnology, BVB College of Engineering and Technology, Vidyanagar, Hubli, India

${ }^{2}$ Institute of Forensic Science, Government Institute of Science, Caves Road, Aurangabad, India

\begin{abstract}
Bacterial cellulose is an exopolysaccharide produced by various species of bacteria such as in the genera Gluconacetobacter, Agrobacterium, Achromobacter, Azotobacter, Rhizobium, Sarcina, Salmonella, Enterobacter etc. In recent years, bacterial cellulose has been focused for the development of acoustic diaphragms, specialty membranes, biomedical wound care products, scaffold for tissue engineering, etc. In this study, effective culture method to produce bacterial cellulose from cheaper and dual carbon sources by Gluconacetobacter persimmonis was examined. Various fruit juices including pineapple, pomegranate, muskmelon, water melon, tomato, orange, and also molasses, starch hydrolyzate, sugarcane juice, coconut water, coconut milk were used as alternative carbon sources for bacterial cellulose production. Out of which muskmelon gave a highest cellulose yield of $8.08 \mathrm{~g} / \mathrm{L}$. Also glucose, fructose, sucrose, maltose, lactose, mannitol, inositol and glycerol were used in combination of two $(1: 1)$ as dual carbon sources. Out of these dual carbon sources, the combination of fructose and sucrose (1:1) gave the highest cellulose yield of $8.79 \mathrm{~g} / \mathrm{L}$. In this study, an attempt was made to reduce the cost of production medium for cellulose by using natural cheaper carbon sources.
\end{abstract}

Keywords: Bacterial cellulose; Gluconacetobacter persimmonis; Cheaper carbon sources; Dual carbon sources

\section{Introduction}

Cellulose is one of the most abundant polysaccharides and is considered as an inexhaustible and unique source of new materials for a wide number of applications [1]. Many species of bacteria, such as those in the genera Gluconacetobacter, Agrobacterium, Aerobacter, Azotobacter, Rhizobium, Sarcina, Salmonella, Enterobacter, Escherichia and several species of cyanobacteria are reported to produce extracellular cellulose [2-4]. This cellulose from bacterial source is called bacterial cellulose (BC). Bacterial Cellulose has many desirable properties such as high purity (free of lignin and hemicelluloses), high crystallinity, a high degree of polymerization, a nano-structured work, a high wet tensile strength, a high water holding capacity, and good biocompatibility [5]. The superior physical properties of bacterial cellulose make it an interesting candidate for possible studies and uses in speaker diaphragms, tourniquet, or dietary fibres. In addition, due to its low toxicity and chemical stability, bacterial cellulose can be used in the manufacturing artificial skin as well as paint used as a thickener for ink [6,7].

Traditionally, BC is produced from expensive culture media, containing glucose as carbon source and other nutrient sources resulting in very high production costs, which limits the use of this material to very high value added applications. The use of cheap carbon and nutrient sources is an interesting strategy to overcome this limitation and therefore to increase the competitiveness of this unique material. Many researchers produced BC using different natural carbon and nitrogen sources [4,8-10]. Mostly, fruits are sold and consumed as raw food, but most of the damaged and non-standard size ones are shelved, though some are processed to make jams, paste's and sauces. When the fruits cannot be shipped because of their poor quality caused by bad weather and other natural disasters, it leads to low prices and fruit wastages. The majority of these wastes end up being discarded. However, such fruits have abundant sugars such as glucose and fructose that could be bio-converted into useful products [9]. The potential application of BC is also limited by its yield. Therefore, strains and production medium must be optimized for higher yield. Another interesting approach for improved production of $\mathrm{BC}$ is the use of combination of carbon sources. A study was carried out to produce cellulose effectively using different carbon sources in the combination of two among which fructose+sucrose gave the highest yield [11].

The present study reported the effect of various natural carbon sources like fruit juices, molasses, coconut water, coconut milk, starch hydrolysate and combination of carbon sources (1:1) on cellulose production by Gluconacetobacter persimmonis $\mathrm{GH}-2$.

\section{Materials and Methods}

\section{Microorganism}

The $\mathrm{BC}$ producing microorganism was isolated from a commercial food source, Nata sample [12]. For the isolation of the bacterial strain, standard Hestrin-Schramm (HS) medium [13] was employed with modifications. The medium consisted of $(\mathrm{g} / \mathrm{L}) \mathrm{D}$-glucose-20; yeast extract-5; peptone-5; disodium phosphate-2.7; and citric acid-1.15; $\mathrm{pH}$ 6.0. The isolate was identified as Gluconacetobacter persimmonis based on biochemical characterization and $16 \mathrm{~S}$ rDNA sequence information. The culture was maintained at $4^{\circ} \mathrm{C}$ on HS agar slants.

\section{Cellulose production from fruit juices}

In this study, pineapple, pomegranate, muskmelon, watermelon,

*Corresponding author: Basavaraj Hungund, Department of Biotechnology, BVB College of Engineering and Technology, Vidyanagar, Hubli, India, Tel: +919449169349; Fax: +91-836-2374985; E-mail: hungundb@gmail.com

Received January 02, 2013; Accepted February 16, 2013; Published February 20, 2013

Citation: Hungund B, Prabhu S, Shetty C, Acharya S, Prabhu V, et al. (2013) Production of Bacterial Cellulose from Gluconacetobacter persimmonis GH-2 using Dual and Cheaper Carbon Sources. J Microb Biochem Technol 5: 031-033. doi:10.4172/1948-5948.1000095

Copyright: @ 2013 Hungund B, et al. This is an open-access article distributed under the terms of the Creative Commons Attribution License, which permits unrestricted use, distribution, and reproduction in any medium, provided the original author and source are credited 
tomato and orange fruits were purchased at a local market. These fruits were washed, crushed, squeezed and separated to the juices and residues. The juices were diluted, filter sterilized and stored at $-20^{\circ} \mathrm{C}$ for future use. The nitrogen sources in the HS medium were added to the fruit juices, and the mixture was adjusted to $\mathrm{pH} 6$ with disodium hydrogen phosphate buffer. Sugar concentration in each experiment was set at $2 \%(\mathrm{v} / \mathrm{v})$ and the dilution was based on the sugar content originally present in the fruit juices.

\section{Treatment of cellulose pellicle}

About $100 \mathrm{ml}$ of each medium contained in $250 \mathrm{ml}$ conical flask was inoculated with Gluconacetobacter persimmonis. The flasks were incubated at $30^{\circ} \mathrm{C}$ for 14 days and observed for pellicle formation. The pellicle formed was removed carefully, boiled in $2.0 \% \mathrm{NaOH}$ for $30 \mathrm{~min}$ and thoroughly washed with distilled water. The drying was carried out at $70^{\circ} \mathrm{C}$ in an oven for $6 \mathrm{~h}$. The dry weight of the cellulose obtained was calculated.

\section{Treatment of molasses}

Treatment of the molasses was done referring to previous study [4]. The crude molasses was diluted fivefold $(\mathrm{w} / \mathrm{v})$ with distilled water and centrifuged at 6,000 rev/min for $20 \mathrm{~min}$ to separate the solid materials. The supernatant was designated as molasses solution. The molasses solution was adjusted to $\mathrm{pH} 3.0$ with $2 \mathrm{M} \mathrm{H}_{2} \mathrm{SO}_{4}$, and heated at $120^{\circ} \mathrm{C}$ for $20 \mathrm{~min}$, retained overnight at room temperature and then centrifuged again at $6,000 \mathrm{rev} / \mathrm{min}$ for $20 \mathrm{~min}$. This treatment was designated as $\mathrm{H}_{2} \mathrm{SO}_{4}$-heat treatment and the supernatant was termed as $\mathrm{H}_{2} \mathrm{SO}_{4}$ heat treated molasses. Total carbohydrate content was determined by Anthrone method [14].

\section{Treatment of starchy substance}

Treatment of the starch material was done referring to previous study [4]. Approximately, $500 \mathrm{~g}$ of potato was cut into small pieces. These pieces were boiled in a water bath for $3 \mathrm{~h}$ in $2.5 \mathrm{M} \mathrm{HCl}$. After boiling, the solution was cooled to room temperature and kept overnight. A known volume $(5.0 \mathrm{ml})$ of this hydrolysate was taken and neutralized by adding sodium carbonate. This neutralized starchy solution was taken for determining total carbohydrate content by the Anthrone method.

\section{Results and Discussion}

\section{Effect of dual carbon sources}

Previous investigation for the production of bacterial cellulose from Gluconacetobacter persimmonis GH-2 showed that the organism could able to use various carbohydrates $(2 \% \mathrm{w} / \mathrm{v})$ for growth and cellulose production [12]. The strain effectively utilized glucose, fructose, sucrose, mannitol and inositol for BC production, giving maximum yield with fructose $(5.56 \mathrm{~g} / \mathrm{L})$. In the production medium, different combinations of pure carbohydrates (1:1) were provided as carbon sources. Figure 1 shows the yield of cellulose after incubation and cellulose estimation. All the combinations of carbon sources were able to give substantial yield of cellulose. Combinations of galactose+sucrose, galactose+lactose, galactose+maltose, galactose+fructose gave cellulose yield of 7.67, 6.89, 6.28 and $5.82 \mathrm{~g} / \mathrm{L}$ respectively. Similarly, fructose+sucrose, fructose+lactose and fructose+maltose gave cellulose yield of $8.79,7.92$ and $6.76 \mathrm{~g} / \mathrm{L}$ respectively. It is noteworthy that, pure fructose gave higher and pure lactose gave lower yields of cellulose but their combination gave highest cellulose yield. Similar study conducted by previous workers also showed combinations of fructose+sucrose and fructose+lactose gave cellulose yield of 6.38 and $5.44 \mathrm{~g} / \mathrm{L}$ [11]. The strain isolated by these workers was from nata (desert) and always been maintained in sucrose containing medium. Also, nata has always been produced using sucrose as the carbon source. Several have reported the presence of invertase in some strains of A. aceti and A. xylinum. The presence of such enzyme would seem to be required for metabolic utilization of sucrose. Our isolate was also obtained from nata sample and could able to use the disaccharides effectively for cellulose production. The effect of two sugars which gave the highest yields of cellulose was examined.

\section{Effect of cheaper carbon sources}

Figure 2 shows the comparison of bacterial cellulose yield from various natural carbon sources. The amount of sugar present in the natural carbon sources was estimated by Anthrone method. Carbohydrate analysis of pineapple juice, pomegranate juice, muskmelon, watermelon, tomato juice, orange juice, molasses, starch hydrolyzate, sugar cane juice, coconut water and coconut milk showed presence of $7.5,10.9,7.0,7.4,2.0,6.9,39,35,18,1.6$, and $3.0 \%$ of total sugar respectively. Figure 2 shows the bacterial cellulose production from various natural carbon sources provided at $2 \%$ in HS medium with $2.0 \%$ peptone, $0.5 \%$ yeast extract, $0.115 \%$ citric acid, adjusted to $\mathrm{pH}$ 6. After 14 days of incubation the cellulose yield was calculated. All the natural carbon sources were able to support growth and cellulose production by Gluconacetobacter persimmonis. When molasses, watermelon, orange juice and muskmelon were provided as carbon and nutrient sources, the organism was able to produce 5.75, 5.98, 6.18 and $8.08 \mathrm{~g} / \mathrm{L}$ of BC. Thus, maximum BC yield was given by muskmelon.

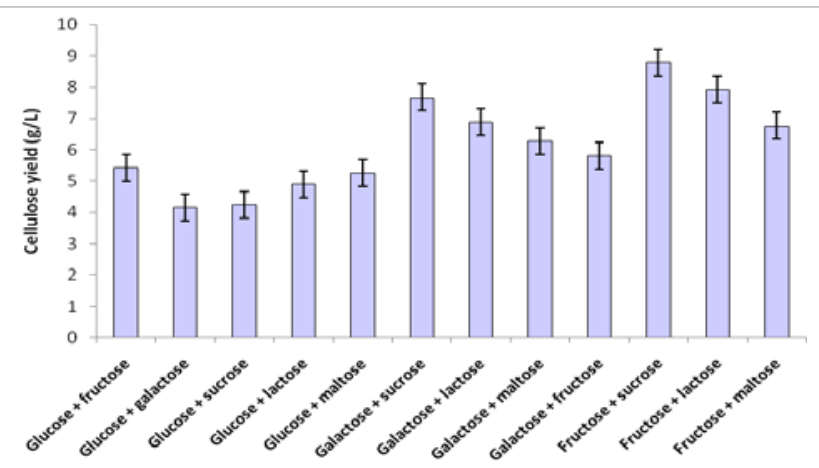

Figure 1: Effect of combination of carbon sources on BC production by Gluconacetobacter persimmonis GH-2 (Note: Same inoculum level was used throught the study).

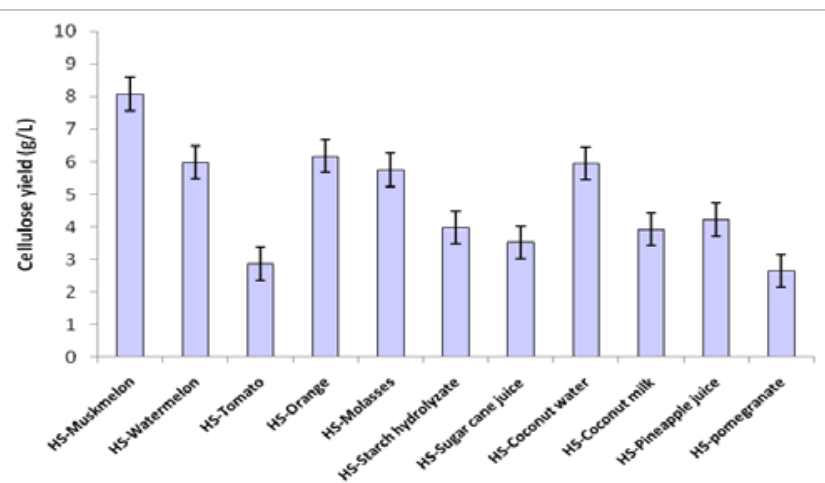

Figure 2: Effect of natural carbon sources on BC production by Gluconacetobacter persimmonis GH-2 (Note: Same inoculum level was used throught the study). 
Citation: Hungund B, Prabhu S, Shetty C, Acharya S, Prabhu V, et al. (2013) Production of Bacterial Cellulose from Gluconacetobacter persimmonis GH-2 using Dual and Cheaper Carbon Sources. J Microb Biochem Technol 5: 031-033. doi:10.4172/1948-5948.1000095

Molasses is widely used in commercial production of various products. However, some undesirable substances in molasses, such as coloring substances, heavy metals and unknown compounds may act as growth inhibitors, the crude molasses needs to be diluted and subjected to acidification and heat treatment. Kongruang [9] used coconut juice and pineapple juice as cheaper carbon sources for BC production. In another study, $\mathrm{BC}$ production was undertaken from various fruit juices including orange, pineapple, apple, Japanese pear, and grape [10]. Their study confirmed that orange and Japanese pear juices were suitable media for BC production. Many fruit juices are rich in carbohydrates, proteins, and trace elements; they can be used as good nutrients for the production of food grade bacterial cellulose. Use of fruit juices should provide economical sources of nutrients for the production of bacterial cellulose.

\section{Acknowledgement}

The authors acknowledge financial support from Vision Group on Science and Technology (VGST), Department of Information Technology, Biotechnology and Science \& Technology, Government of Karnataka. Authors also acknowledge encouragement from Dr. Ashok Shettar, Principal BVBCET, Hubli, India.

\section{References}

1. Huber GW, Iborra S, Corma A (2006) Synthesis of transportation fuels from biomass: chemistry, catalysis, and engineering. Chem Rev 106: 4044-4098.

2. Napoli C, Dazzo F, Hubell D (1975) Production of cellulose microfibrils by Rhizobium. Appl Microbiol 30: 123-131.

3. Ross P, Mayer R, Benzimann M (1991) Cellulose biosynthesis and functions in bacteria. Microbiol Mol Biol Rev 55: 35-58

4. Hungund BS, Gupta SG (2010) Production of bacterial cellulose from
Enterobacter amnigenus GH-1 isolated from rotten apple. World J Microbio Biotechnol 26: 1823-1828.

5. Yoshinaga F, Tonouchi N, Watanabe K (1997) Research progress in production of bacterial cellulose by aeration and agitation culture and its application as new industrial material. Biosci Biotechnol Biochem 61: 219-224.

6. Shibazaki H, Kuga S, Onabe F, Usuda M (1993) Bacterial cellulose membrane as a separation medium. J Appl Polym Sci 50: 965-969.

7. Klemm D, Schumann D, Udhardt U, Marsch S (2001) Bacterial synthesized cellulose artificial blood vessels for microsurgery. Prog Polym Sci 26: 1561 1603.

8. Thomson DN, Hamilton MA (2001) Production of bacterial cellulose from alternate feedstocks. Appl Biochem Biotechnol 93: 503-513.

9. Kurosumi A, Sasaki C, Yamashita Y, Nakamura Y (2009) Utilization of various fruit juices as carbon sources for production of bacterial cellulose by Acetobacter xylinum NBRC 13693. Carbohydrate Polymers 76: 333-335.

10. Kongruang $S$ (2008) Bacterial cellulose production by Acetobacter xylinum strains from agricultural waste products. Appl Biochem Biotechnol 148: 245256 .

11. Hungund BS, Gupta SG (2010) Improved production of bacterial cellulose from Gluconacetobacter persimmonis GH-2. Journal of Microbial \& Biochemical Technology 2: 127

12. Embuscado ME, Marks JS, BeMiller JN (1994) Bacterial cellulose. I. Factors affecting the production of cellulose by Acetobacter xylinum. Food Hydrocol 8: 407-418.

13. Hestrin S, Schramm M (1954) Synthesis of cellulose by Acetobacter xylinum II. Preparation of freeze-dried cells capable of polymerizing glucose to cellulose. Biochem J 58: 345-352.

14. Dreywood R (1946) Qualitative test for carbohydrate material. Ind Eng Chem Anal Ed 18: 499 